Jessop, S. (2018). How modernity's futurism puts children in the front line. Childhood.

\title{
How modernity's futurism puts children in the front line
}

\section{Introduction}

Yesterday, as I write, a 22 year old blew himself up at a pop concert, killing 22 and injuring 59. ${ }^{1}$ The people attending the concert were very young and mainly female: the youngest victim was an 8-year-old girl. Some of the other victims were there to accompany or collect their children. The media coverage today is furious and sentimental in equal measure, lingering on photographs of the girls, recounting their purity and virtues and commenting on their beauty. One young man who died was described in terms of his close relationship with his mother (his male partner was barely a footnote). The emotional amplification in the media's treatment of this event contrasts to the defiant tone in coverage of previous attacks such as the 2005 bombings in London. The latter consistently featured 'enacted images of Britishness' and a 'prose of solidarity' (Matthews 2014, p.1; Schudson 2002, cited Matthews 2014, p.2) whereas this event is presented as one of violated childhood and devastated mothers and fathers. ${ }^{2}$

Why is this? There are a number of possible answers: our failure to protect children is a psychological insult; children are not culpable in relation to whatever moved the attacker; children have more years of life ahead of them, so the loss seems greater. But still the strength of the reaction seems to need a better explanation. In considering this question, it is conspicuous that understandings of the attack involved the criss-crossing of paradoxical sexual and sentimental normative ideas. Ultra-conservative evangelical Christians in the US floated to the surface on social media within hours to condemn the concert performer as 'degenerate' and 'pro-Sodomite' (see, for example, Duffy 2017). The same people called the victims 'sluts' and 'whores' whilst mourners and newspapers described them as 'angels' and 'innocents'. Overall the discourse was steeped in strong moralistic and symbolic imagery.

The physical and economic vulnerability of children can put them in danger: children can be killed by their parents, in school shootings, by traffickers, or by neglect. They have long been targets in war and this continues in present conflicts (Campos, 2014). There is a 'perilous

\footnotetext{
1 The Manchester Arena bombing on the $22^{\text {nd }}$ May 2017 was detonated at the end of a concert given by the American singer Ariana Grande, who is particularly popular with young girls and is an LGBT ally. For a survey of the next day's media coverage see (Rawlinson, 2017)

${ }^{2}$ Compare, for example, these headlines, the first from 2005, the second 2017:

'We Britons will never be defeated'/ 'How could jihadi barbarian murder our beautiful and innocent children?' (Daily Express);

'Bloodied but unbowed' /'Pictures of innocence....killed by evil' (Mirror) (Ridley, 2015).
} 
Jessop, S. (2018). How modernity's futurism puts children in the front line. Childhood.

logic' (Myers-walls, 2008: 42) to the killing of children in these situations: ethnic superiority, ethnic cleansing, genocide, cutting a bloodline and its claims to territory, destroying children who may grow up to seek revenge. Terrorism is distinctive: it is fundamentally rhetorical or communicative. The symbolic meaning of the victims, of the place or the occasion is important (Crimmins, 2006; Tuman, 2010). Modern terrorism is defined by the notion of 'propaganda by deed'3 : for the perpetrator there are no 'innocent victims' - the individual is subsumed in a category or is guilty by association. ${ }^{4}$ Their death is 'more than real' - it is symbolic and sacrificial (Baudrillard \& Turner 2012: 17). The idea that attacks are random or indiscriminate is often proposed (for example, Baur 2005: 13ff) but this notion is enabled by a perspective that refuses to recognize the terrorists' actions as communicative and therefore rational.

The particular event with which I have opened this discussion, though in some ways just one of many possible examples where children have been targeted victims, is also distinctive in bringing together a constellation of elements which highlight the symbolic importance of children where violence is used.

This paper will consider two conceptions of child in order to explore this symbolism: a concept of child which reflects the axioms of modernity; and the negation of this dominant idea as it is found in Surrealism and in Queer theory. Little attention has hitherto been given in this context to the manifestations of modernity in artistic movements. The Surrealist movement's explicitly anti-modern treatment will be explored as an original instance of the 'queering' of our concept of child, which has long been a form of resistance to dominant paradigms of progress that characterize modernity and, amongst other things, put children in the front line of adult ideological wars.

\section{Modernity's futurism and the 'iconic child'}

Modernity is characterised by a reverence for progress and by belief in the unquestionable preeminent value of the future. It is not simply a continuing chronological category but signifies an important (and irrevocable) break with past assumptions and ways of thinking (Pippen, 1999: 17). Foucault similarly describes modernity as not a period of history so much as an attitude, a way of thinking and feeling, acting and behaving, a task, even (1984: 39).

\footnotetext{
${ }^{3}$ A phrase coined in 1876 by Italian anarchists (O'Kane 2007: 14)

${ }^{4}$ In his trial for a 1894 terrorist attack, Emile Henry said, 'What about the innocent victims? .... The building where the Carmaux Company had its offices was inhabited only by the bourgeois: hence there were no 'innocent victims'.' ( $(0$ 'Kane 2007: 18)
} 
Jessop, S. (2018). How modernity's futurism puts children in the front line. Childhood.

Modernity is characteristically enthralled to the foundational dogma of progress, the 'animating and controlling idea of western civilisation' (Bury, 1920: vii), the notion that by means of science and technology our lives will be better: liberated from labour, materially better off, and full of exciting new possibilities. Tradition and all that it entails: community, shared habits and inherited beliefs, is that from which the modern mind disembeds and disencumbers itself. Modernity is in this sense a perpetual breaking with the past; it is crucially forward-gazing. And this particular relation to time is what gives the concept of the modern child its distinctive elements.

David Kennedy's observation that each age has its 'iconic child' that reflects a certain problem or preoccupation is a helpful one (2013). The relatively recent paradigm of childhood as a cultural phenomenon derives from sociological approaches with an interest in unveiling the construction of childhood as an axis of power, determined in part by its relation to adjacent concepts such as adulthood or the non-human. The word 'icon' is now generally used very loosely, but if we recover its origins in a theology of incarnation, it powerfully draws our attention to the way in which the child in a sense can become a monstrance or vessel for a society's hopes and fears and, rather than a passive reflection or imprint of context; the child in the imagination stands as a living embodiment of a set of ideas or affects. Kennedy's conclusion that this iconic child therefore signifies futurity should be qualified. The problems or preoccupations of each age must in a sense always be about the future: what will happen next, what will happen if, what preparations need to be made to ensure a desired outcome? But in the modern era, at least in a western or European context, the way of thinking about the future has changed and intensified. Two principal phases in the relation between the child and modernity can be distinguished, namely: the invention of childhood and the centring of childhood.

The construction of childhood with which we are most familiar, namely childhood as a substantively distinct form of life, representing our irrational pre-scientific selves, arose concurrently with the scientific world-view (Kennedy, 1989: 377). This is what has become known as 'the invention of childhood', a phrase that points to a significant alteration in adult ideas about this life stage. The modern iconic child seems to dispense with more complex ideas of the child bearing the name, traditions, beliefs and habits of their inherited past into the future. Modernity's rupture with the past gives us a simple futurity with a passionate belief in, and longing for, progress. But even this sense of the future was to be further ratcheted up in the 20th Century. Our furious obsession with the future started to peak at around the turn of the $19^{\text {th }}$ Century. This early phase presages the confidence in progress of high modernity: the hope of social, economic and moral betterment that was increasingly 
Jessop, S. (2018). How modernity's futurism puts children in the front line. Childhood.

invested in children. There is perhaps no better example of this than in the writings of the Swedish education reformer Ellen Key. Her conviction that the human race was ascending to 'an ever richer completeness', was coupled with an escalation in the politicization of childhood. The ascent of the human race was accompanied by a corresponding categorical imperative that it was the responsibility of the young to fight for the realization of the "new society' (Key, 1914: 11, 181). Consequently, there is no more important human activity than the rearing of children - this is what she called 'the holiness of generation' - in what she excitedly declared to be the 'Century of the Child':

$[T]$ he central work of society, the new race, its origin, its management and its education: about these all morals, all laws, all social arrangements will be grouped. This will form the point of view from which all other questions will be judged, all other regulations made. (Key, 1900: 3)

We have seen a further intensification of this centring of the child in the last 3 decades since the UNCRC (The United Nations, 1989). Children and childhood now dominate a number of public policy agendas (James, Jenks \& Prout, 1998: 5). There is an increasing sense of urgency around globalisation, national security, social cohesion, and environmental sustainability that has given rise to a focus, in particular, on education and the family as a way of gaining traction on these issues. Children's rights now dominate policy discourse, though, significantly, not the lived experience of many children. The notion of child-centredness has become axiomatic across the spectrum of public policy concerning children and families, though the term is used with little consistency and even less definition (Chung \& Walsh, 2000). This is a shift from the belief that children are icons of a glorious future to the idea that children are our only hope that there will be a future, a change from happy progress to redemption. Sensing our impending self-wrought destruction, we have turned to the child.

\section{The 'holiness of generation', Radiant Babies, and reproductive futurism}

The evangelical tone of Ellen Key's writing is truly of its period, and both its absolutism and optimism are dissonant with our own more relativist and pessimistic time. The "holiness of generation' might sound more Margaret Atwood ${ }^{5}$ than Karl Marx, but there is still considerable resonance with powerful contemporary childhood motifs. This is energetically exposed in Lee Edelman's critique of 'the pervasive invocation of the Child as the emblem of futurity's unquestioned value' and the 'reproductive mandate inherent in the logic of

\footnotetext{
${ }^{5}$ Margaret Atwood's Handmaid's Tale (1985) is a dystopian novel in which women's reproductive function becomes their only defining feature.
} 
Jessop, S. (2018). How modernity's futurism puts children in the front line. Childhood.

futurism' (2004: 117). His argument is anti-child but the child he is talking about is an historically and culturally mediated idea. The child-idea, with all its attendants, becomes the measure of what is good and worthy, just as Key wished for more than a century ago. Childrearing, parenting, and, in particular, motherhood, all bask in the light of the Radiant Baby. ${ }^{6}$ In the symbolic order the child is fused with the future and has become what Michael Cobb (2005: 124) has called 'the worst kind of political brat' - unquestioned, unquestionable, always first, silencing all other claims on our attention, and just as the over-indulged child in real life ultimately wreaks havoc, there are consequences in the polity: the promotion of 'Family values' at the expense of women's reproductive rights and the civil liberties of LGBT people has recently gained significant ground; environmental protection and the welfare of other animals is at best a fringe event in public policy discussion; the child that must be cherished and protected turns out to be a white American or European. Modernity's passion for progress has been waylaid by the futurism of late modernity; the quasi-religious zeal that centres the child as the locus of redemption not only opens the polity to regressive antisecular forces, but also presses children to the front line of ideological dispute. In this case, we should not be taken by surprise when children become targets not only of social ameliorists, but also of ideological warriors.

\section{Modernity and art}

Just as the noise of modernity's futurism started to rise at the turn of the $19^{\text {th }}$ Century, so also did counter-modern voices of criticism. Pippen (1999) describes how in contemporary criticism, 'everywhere the figures and images had been and are again the images of death and loss and failure, and the language of anxiety, unease, and mourning' (Pippin, 1999: xii). The resistance in the early decades of the last century was literary, philosophical, sociological, spiritual, and artistic. The inclusion of artistic movements in philosophical accounts of modernity is not common (Taylor being one exception) but this is a pity since these movements not only make the ideas under discussion literally visible, but also in some cases provide a rich source of explicit articulations of attitudes to modernity in the form of manifestoes and other writings. For present purposes it is also important since it explains something of the intellectual and aesthetic correspondents of the futurism that is discussed here, and leads to the distinctly anti-modern Surrealist concept of child. But first some context.

\footnotetext{
${ }^{6}$ 'Radiant Baby' c1980 by Keith Haring (1958-1990) became one of the $20^{\text {th }}$ Century's most reproduced images of the child. (Haring \& Fairey, 2010, p.xvi) Haring, who was a gay man and human rights activist said of this image, 'Babies represent the possibility of the future, the understanding of perfection, how perfect we could be. There is nothing negative about a baby, ever.' (Haring \& Fairey, 2010, p.xxv)
} 
Jessop, S. (2018). How modernity's futurism puts children in the front line. Childhood.

Three phases of the relation of art to modernity may be distinguished: until the early years of the $19^{\text {th }}$ Century most artists had, at best, an ambivalent attitude to the idea of progress, at worst, they detested it (Spender, 1963: x). Nineteenth Century interest in 'primitivism', the recasting of craft-work as an art form, with its hallmark irregularity, and the focus on the individual, nature, and the human form, all attest to a distrust of technology and mechanization (Herbert, 1997: 1275).

But around $1910^{7}$ something changed: it has been proposed that the inevitable encroachment of mass production, combined with the domestication of machinery, the 'arrival of the machine', led to an abrupt volte-face (Herbert, 1997). The 'machine aesthetic' was endorsed in different ways by Cubists, Vorticists, Bauhaus, Constructivists and others across the European continent (Herbert 1997: 1275). But Futurism was preeminent among the activist, militant vanguard movements, what Forgács terms the 'avant-garde' of the modernists (2014: 30). And it is from this quarter that we have the most extreme and explicit endorsements of the dogma of progress, admiration for technology and an exclusive future-orientation. The Futurist manifesto, written by its greatest exponent, Umberto Boccioni in 1910, is very close to the style and content of Ellen Key's Century of the Child:

Comrades, we tell you now that the triumphant progress of science makes changes in humanity inevitable, changes that are hacking an abyss between those docile slaves of tradition and us free moderns who are confident in the radiant splendour of our future. (Manifesto of the Futurist Painters 1910, in Rainey et al., 2009: 62)

The adoration of the present, and what of the present most seems to represent the future, along with the dismissal and hatred of age and tradition, seems to figure to the point of caricature the core doctrines of modernity. Futurism as an artistic movement was swept away by the events of the years following the publication of their manifestoes, by personal tragedies, war, and assimilation into fascist ideologies (Humphreys, 1999: 66-76). The broken promises of technology are a significant theme in modernity's critique; Futurism appears late on, like something of a morality play about the folly of modernity's hubris.

\section{Counter-modernity and art: 'The futurist is dead. What killed it? Dada.' 8}

Two oppositional movements emerged during modernism's accommodation to the machine. For some, the carnage of the First World War gave the lie to the promise of progress through

7 The Nazi party declared avant garde art produced after 1910 to be 'degenerate' (Peters, 2014: 21).

${ }^{8}$ (Jones 2014: 17) 
Jessop, S. (2018). How modernity's futurism puts children in the front line. Childhood.

technology. First Dada, then Surrealism, rejected the individualist, rationalist, and futurist orientation that in different forms and combinations characterised other artist movements of the time.

Dada was a truly international movement which came onto the scene first in New York and Zurich in 1915/16 and then in Germany and France, before giving way to its successor, Surrealism, in the early 1920s (Herbert, 1997: 1293-1294). Dada's relation to time is of particular interest here. Like the Futurists, Dadaists pursued the 'total dissolution of the past', and the 'total negation of everything that had existed before', and yet their vision did not extend to an idealised future (Richter, 1965: 48). Maria Stavrinaki's superb essay Dada Presentism (2016) captures Dada's philosophic stance and its indebtedness to Nietzsche's critique of historicism in imagery drawn from Walter Benjamin's 'Theses on the Philosophy of History' (1968):

For... the Expressionists and Futurists - the pulverized past made it all the more easy to construct a hypertrophied future... But there were also artists for whom the view from the field of ruins revealed a blocked horizon. Such were Dadaists. (Stavrinaki, 2016: 5)

Dada lacks the explicit formulations of childhood we find in Surrealism, but the child is nonetheless a strong presence. The name itself (though explanations vary ${ }^{9}$ ) recalls a child's first word, and Dada celebrated its own 'immaculate conception', denying any artistic lineage (Stavrinaki, 2016: 79). Dadaists revelled in playful nonsense, developed the previously juvenile medium of photomontage and some, notably Hannah Höch, used dolls and puppets in their work. Futurists instrumentalize the present, valuing it only insofar as it is pregnant with the future. Dadaists are 'children of the present' (Stavrinaki, 2016: 9). Dada lasted less than a decade till many of its ideas, techniques and proponents migrated into a new artistic movement, Surrealism, in 1924. But its opposition to futurism's optimism marks the most complete intellectual breaking of the faith with modernity.

Surrealism became one of the most influential ideas of the $20^{\text {th }}$ Century and it presents an exceptional treatment of childhood in relation to counter-modernity. Its contribution is absent from childhood studies literature though it has been explored in more recent studies in art history, notably by David Hopkins (Hopkins, 2014; 2016). Much more than an artistic

\footnotetext{
${ }^{9}$ Richter (1965) gives 7 versions of the word's origin and this is not one of them. One of these theories relates it to what
} in German is 'an indication of idiot naivety and of a preoccupation with procreation and the baby carriage' (31) 
Jessop, S. (2018). How modernity's futurism puts children in the front line. Childhood.

movement, 'surrealism at its inception was intended to be a way of thinking, a way of feeling, and a way of life' (Waldberg, 1965: 12; Strom, 2002). The politics of Surrealism are complex; this is an unusually long-lived movement that manifested differently in different places. The original French group were Communist Party members in France but they were an uneasy fit: too bourgeois, too independent and individualist, and, ultimately, too absent during the Occupation (Hopkins, 2004, pp. 141-144). ${ }^{10}$ Walter Benjamin recognised in André Breton (the first and foremost in this group) that he was 'the first to perceive the revolutionary energies that appear in the 'outmoded"' (Benjamin, 1999: 210). Both the Frankfurt School and the Surrealists were strongly influenced by Freudian theory of the subconscious, the importance of dreams (Jay, 1973, pp.86-112), memory, the idea of the recovery of what is lost or extinct in a dialectic with the present: the 'strategic re-valorization of the things that had been marginalized or repressed' (Hopkins, 2016: 1043).

Romanticism is the first, and remains the principal, articulation of this sense of loss that accompanies modernity from the point of its ascendency in the middle of the 18th Century. It is also modernity's original opposition, and the Surrealists understood their own movement to be its apotheosis. Breton described the movement as a newly articulate child grown from the infant Romanticism: "What has wrongly been called [Romanticism's] heroic period can no longer be considered as anything but the first cry of a newborn child which is only beginning to make its desires known through us." (1969: 153).

Romanticism is an unruly intellectual cluster: though most associated with the period from mid-18th to mid-19th Centuries, its reach stretches over more than two centuries and includes widely divergent emphases, ends, and media. However, it is consistently characterised by the 'rejection of contemporary society, an experience of loss, a melancholic nostalgia, and a quest for the lost object', but more fundamentally: 'Romanticism represents a critique of modernity, that is, of modern capitalist civilization, in the name of values and ideals drawn from the past (the precapitalist, premodern past)' (Löwy \& Sayre, 2001: 17). Not coincidentally, the 18th century was when a new sensitivity to childhood began to take shape ${ }^{11}$, and the child emerged in literature as an accommodating symbol for a variety of responses to a rapidly changing environment (see Peter Coveney's seminal study of the child in literature, Poor Monkey, 1957). The Romantic child was the negation of modernity and its disenchanted, calculating,

\footnotetext{
${ }^{10}$ Many exiled Surrealists were politically active (Mahon 2007: 52). They were targeted alongside others as 'degenerate artists' (Barron et al., 1991; Peters, 2014)

11 The idea that childhood somehow started in the $18^{\text {th }}$ Century has to be treated with caution, both in view of much earlier evidence and also in acknowledgement of the gendered and colonial nature of the claims to have 'discovered' childhood as a 'new continent ... a domestic colony, a remembered internal realm, an accessible otherness' (Plotz, 2001: 2).
} 
Jessop, S. (2018). How modernity's futurism puts children in the front line. Childhood.

instrumental rationality, standing instead on the 'side of Imagination or Spiritual Sensation' (William Blake, 1799 cited Coveney 1957: 14). This child existed in a 'state of Nature' and, lacking experience, a state of naïve original innocence. But by the end of the twentieth century Sigmund Freud's theory of the polymorphous perversity of infantile sexuality had started to disrupt the specific asexual understanding of that innocence. ${ }^{12}$ And this is where Surrealism picks up the challenge to modernity in the figure of the child.

For Surrealists childhood is a time when we access states of mind that become increasingly elusive as we enter adulthood. This is connected to the notion of 'child-time', a 'transfigured conception of time and space' in which "the self is 'unintegrated', and therefore open to all possibilities" (First Surrealism Manifesto 1924 cited Leppanen-Guerra, 2011: 6) Just as Benjamin speaks of the child's preoccupied 'pure receptivity' alongside her voracious and irreverent consumption to the point of destruction, the Surrealists found in the figure of the child a locus for the anarchic and oneiric, a lost self that was closer to subconscious desires, and subject to irrational terrors. Max Ernst wrote about his childhood as a time of 'excursions in the world of marvels, chimeras, phantoms, poets... magi' (Max Ernst (1948) Beyond Painting, cited Hopkins, 2016).

The Surrealist 'cult of the child', in particular, the 'woman-child' - femme-enfant - was a recurring motif in surrealist writing and painting (McAra, 2011: 3; Hopkins 2014: n.p.). The 'woman-child' is an elision of childhood and adulthood that takes different forms. Sometimes young females are objectified and sexualised (such as in Hans Bellmer's unsettling series of 'dolls' posed in ways that suggest violation and dismemberment). Elsewhere we find girls moving through fantastical dreamscapes or nightmares (for example, Max Ernst's Two Children are Threatened by a Nightingale, 1924) or in magical scenes reminiscent of fairy tales (for example Joseph Cornell's Bébé Marie, c1940 in which a girl doll stares out through thick twigs, like a child lost in a forest, or his Tilly Losch, 1935 in which a young girl is suspended in a tub over snow-covered mountains).

Of particular importance in understanding the Surrealist femme-enfant is the figure of Lewis Carroll's Alice. Alice in Wonderland (1865) had an international readership and was part of the early literary experiences of many within the movement growing up in the late $19^{\text {th }}$ and early $20^{\text {th }}$ Centuries. In this character, a bold, curious little girl on the cusp of adulthood, Surrealists found an icon for their distinctive presentation of childhood. Catriona McAra

\footnotetext{
12 Steven Marcus describes Freud as 'one of the last great legatees of the Romantic tradition in European thought'. The difference being that ' $\mathrm{t}$ ] here is recognition and remembrance of bliss and satisfaction in his world but there is no music of the spheres' (Marcus 1984: 38-39)
} 
Jessop, S. (2018). How modernity's futurism puts children in the front line. Childhood.

(2011) explores in detail the presence of Alice and her significance in the Surrealist movement, which recognised the 'transgressive function' (5) of her curiosity, which leads her into a fantastical, dangerous, violent and cruel world through which she is able to navigate her way because of her cleverness and courage.

The American author and painter, Dorothea Tanning is one of the most intriguing Surrealist artists in her use of the girl-child or Alice figure. Her paintings of pubescent girls contain all the elements of nightmarish fear, corruption and trauma but the depictions are also magical and powerful: they show children engaged in complex and intelligent dreamscapes of time and the natural world (Glăvan, 2016). These children are not animalistic, impulsive and irrational but, like Alice, they are unafraid, absorbed, sensual and enchanted. Tanning's 'wise children' (or, rather, her 'terrible little girls') are portrayed, for example, in her painting, 'Children's Games' (1942), ripping off wallpaper with a

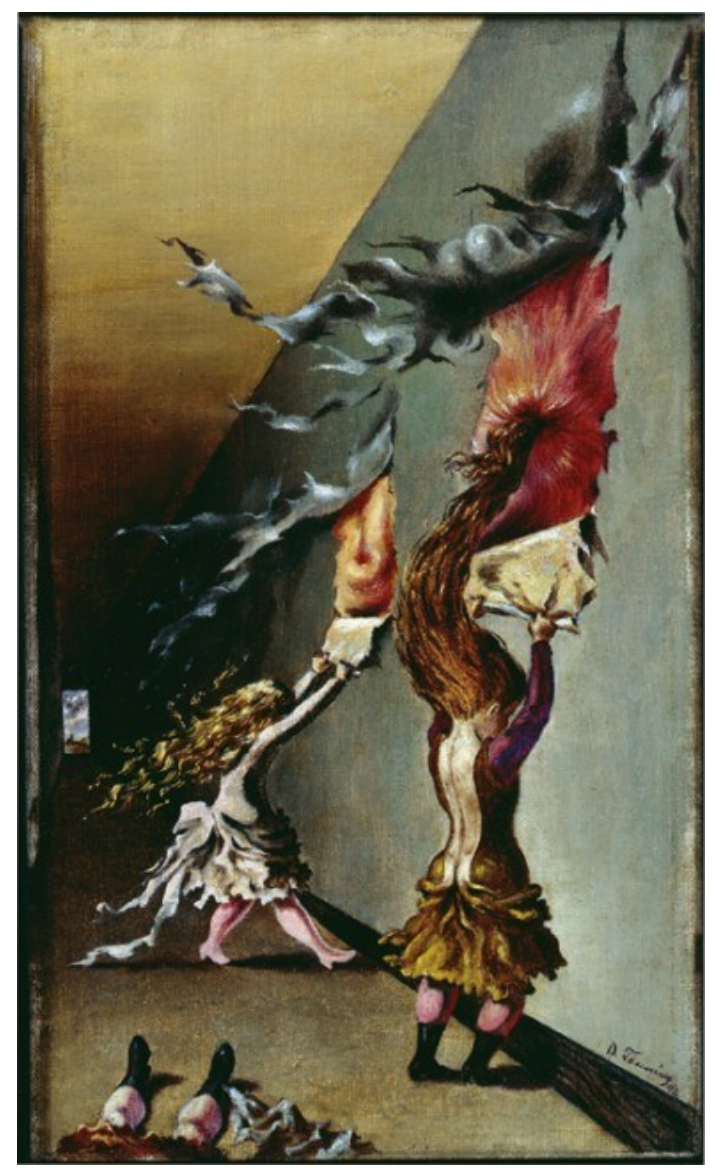
another lying prone - unconscious or dead (we do not know) - with just her legs visible in the painting's frame (Caws, 1997: 84). As Alyce Mahon puts it, 'these girls are half Lewis Carroll's Alice in Wonderland, half the Children's Games 1942 Marquis de Sade's re-educated Eugenie' (C) 2013 The Dorothea Tanning Foundation http://www.dorotheatanning.org/index

(2007: 153). The children both wreck and merge with the room, and its exposed fleshy walls. As the paper is pulled down the walls come alive: tempestuous, bloody and sexually suggestive. This is not simply a picture of partially undressed children destroying a room; this is a 'rough magic' ${ }^{13}$. As she herself said of her work: 'I read somewhere that what I believed to be poetic and sublime testimonials of my conviction that life is a desperate confrontation with unknown forces are in reality cute girlish dreams, flaring with sexual symbols'. ${ }^{14}$ Jean- Christophe Bailly's lyrical assessment of her work accords with her own:

\footnotetext{
13 Shakespeare, The Tempest Act 5 Scene 1

14 From "Questions pour Dorothea Tanning entretien avec Alain Jouffroy, Mars 1974," in Dorothea Tanning: Oeuvre, retrospective exhibition catalogue, Paris: Centre National D'Art Contemporain, 1974: 48. Translated and quoted in elles@centrepompidou: Women Artists in the Collection of the Musée national d'art moderne, Centre de création industrielle, exhibition catalogue, Paris: Centre Pompidou, 2009: 37.
} 
Jessop, S. (2018). How modernity's futurism puts children in the front line. Childhood.

Not the lost paradise of grown-ups' nostalgia, but childhood already overwhelmed by the fluxions of discovery and by the songs it hears chanted under its skin....[I]n these oneiric images, where the dream datum is so sudden, so material, so alive, it is not only nameless desire that trembles within the walls it seeks to explode, but something more obscure, where desire is merely its ecstatic vehicle. (Bailly and Morgan, 1995: 18)

Tanning's settings are often ordinary, domestic: a classroom, a dowdy hotel, a smart apartment. The revolt against this bourgeois order is inevitably gendered: the 'convention that assumes a correlation between a tidy house and a pure, inviolate feminine body' is confronted by the intrusion of monstrous flowers, torn walls, a dropped cigarette, and, worst of all, the déshabillé of its young female occupants (Conley, 2013: 125). A consistent theme in Surrealist art is the aim to 'lay waste to the ideas of family, country, religion' and what Tanning called the 'dove-coterie' categories of gender are at the axis of these ideas (Breton, 1969; Conley, 2013; Mahon, 2007; McAra, 2011; Tanning, 1990).

Chris Jenks' distinction between the Apollonian and Dionysian child is often cited in Childhood Studies literature (Jenks, 1996). The categories are borrowed from Nietzsche, though their meanings are significantly altered. Rather than the on-going creative antagonism between opposing forces, Jenks describes a sort of Manichean dualism of good and evil, innocence and corruption that describes alternative ways of understanding the child: in Christian theology, the pre-lapsarian and the fallen child. The Surreal child tilts away from Jenks' categories altogether: the transgressive behaviour of Tanning's 'terrible little girls' is not evil or demonic. Jenks' description of the Dionysian child as expressing 'a single-minded solipsistic array of demands in relation to which all other interests become peripheral' (Jenks, 1996: 63) has little bearing on the child of Surrealism, who loses herself in the blurring of distinction between polarities of the animate and inanimate, self and other, mind and nature, male and female. Bearing Surrealism's ‘long-range weapon of sexual cynicism' (Breton, 1969: 129) this child is also not in a reverie of innocence and beauty, recapitulating civilisation's pre-enlightenment self. The Surrealist's child is very uncooperative, and decidedly queer.

The sheer strangeness of the child in Surrealism, the subversion, inversion, deconstruction, and mischievousness of its treatment of childhood anticipates contemporary ideas of 'queerness'. Kathryn Bond Stockton (2009), begins The Queer Child with these words: 'If 
Jessop, S. (2018). How modernity's futurism puts children in the front line. Childhood.

you scratch a child you will find a queer, in the sense of someone 'gay' or just plain strange' (p.1). This is the child that Edelman leaves behind (Cobb, 2005). The child that he tells us about is a repository of fetishistic and sentimentalised cultural identifications and utopian fantasy, obediently banking the political capital society invests in it. Does anyone, or can anyone, defy this political brat? Queerness is oppositionally defined: it is 'whatever is at odds with the normal, the legitimate, the dominant. There is nothing in particular to which it necessarily refers' (Halperin, 1995: 62). For Edelman, queerness as a 'child-aversive, futurenegating force' is the primary way of being that can 'cut the thread of futurity' (2004: 30). ${ }^{15}$ Stockton's interest is in the 'estranging, broadening, darkening forms of the child-as-idea', which turns its back on the developmental, forward thrust of modernity and instead grows 'sideways' (3). Less likely to follow the heteronormative trajectory of marriage and reproduction, the gay child is at the heart of Stockton's pursuit. But the queerness of children generally, their opposition, disruption and negation, propels an alternative conceptualisation of childhood to that described by Edelman. 'Sideways growth' is used to 'refer to something ... that locates energy, pleasure, vitality, and (e)motion in the back-and-forth of connections and extensions that are not reproductive' (Stockton, 2009: 13). This is the same child that we find in the work of Surrealists such as Tanning. It is the queer child that stalks the progeny of late modernity's vicious and narcissistic dotage.

\section{Conclusion}

Childhood Studies is still a relatively new and developing terrain. In this there are already signs of what has been called a 'new wave' of thought that draws upon continental European philosophy, and which veers away from the categories and dualities of previous models, instead using notions of hybridity, complexity and indeterminacy (Ryan, 2011). This runs straight up against precisely those rigid conceptualisations that are deployed by all sides in the event with which I opened this discussion. The murder of children constitutes an emergency and the urge to act decisively in these circumstances becomes a clamour that drowns out the need to think. Whatever helps us to understand and gain some traction on these circumstances is valuable. Theorists of childhood have at times been dismissive of what have been described as 'presociological' conceptions. This is unfortunate. 'Common sense', classical philosophy and developmental psychology have been lumped together and consigned to the 'dustbin of history' for what is seen as their essentialising, unhistorical, non-sociological ways (James, Jenks \& Prout,1998: 9). Clearly sociological approaches, from Philip Aries’ Centuries of

\footnotetext{
15 Two codicils are needed here: firstly, the fact that LGBT+ people can and do have children is not in question: queerness is not used here as an identity category, and certainly not as a catch-all for non-heterosexualities; secondly, opposition to reproductive futurity cannot be sublated into a synthesis of the two opposing positions: queerness is always a negation.
} 
Jessop, S. (2018). How modernity's futurism puts children in the front line. Childhood.

Childhood (1960) onward, have helped our understanding of how different understandings of childhood fit each social structure and how the experience of childhood is geo-temporal, not universal. But the condescending tendency of this sociological positivism is unhelpful because childhood is also a history of ideas, and social research methods on their own cannot hope to comprehend the way in which ideas are socially and culturally mediated.

In late modernity the need for order and certainty is predictably increasing in step with anxiety about the future and increasing frustration, for some, at the erosion of normative tropes that helped people orientate themselves in their social world. The idea of childhood innocence and the 'pervasive invocation of the Child as the emblem of futurity's unquestioned value' (Edelman, 2004: 3-4) are two such themes. The sexualised and sometimes paedophilic nature of some Surrealist work may be partly responsible for a certain amount of academic silence on this topic, in a social context where any non-clinical discussion may be met with suspicion and hostility ${ }^{16}$. The contemporary dogma of childhood's asexuality, or, contrariwise, its 'straightness', is an indispensable aspect of the futurist icon. In contrast, Surrealism's transgressive politicised eroticism, condemned by the Nazis as degenerate (in this context a most interesting designation), is at the core of their rejection of modernity and their resistance to totalitarian ideology.

The child-as-idea is a powerful signifier of what moves a society, what it dreads, and the future it wants. This paper has sought to present two oppositional ideas of the child under the conditions of modernity. In the futurist child and the queer child we can see two moments in the modernist/anti-modernist dialectic. There is no intended suggestion that a synthesis of these two ideas will be some kind of advance, and I agree with Edelman, who is adamant that the queer rejection of identity is oppositionally defined and that it cannot be translated into a determinate stance (Edelman, 2004: 4). So the presentation of the two conceptions side-byside is not preparatory to a pseudo-Hegelian negation of the negation. Nonetheless an uncritical adoption of reproductive futurism is endangering us and alternative ways of thinking may furnish some protection. The futurist child is a vehicle for the political aspirations of political and religious conservatives to clip the wings of social liberalism. The 'holiness of generation' has been turned into a weapon against women, LGBT people and anyone who does not fit the normative diktats of 'family values'. This is itself harmful to children but it also pushes them to the ideological front-line. As signifiers of a specific vision of the future, they become child-soldiers for that vision. The recognition of childhood's

\footnotetext{
${ }^{16}$ For example, James Kincaid faced calls in the UK Parliament for his academic work on children and sexuality to be banned, and demands that he be dropped from a conference program (Bruhm \& Hurley 2004: xxxiii; Rush 2013).
} 
Jessop, S. (2018). How modernity's futurism puts children in the front line. Childhood.

profane attitude to the credo of modernity can be part of resistance to increasingly

instrumentalized ways of thinking about children in the polity, in schools and families.

\section{$\underline{\text { Acknowledgements }}$}

I am very grateful to Dr Claire Cassidy and Dr Ralph Jessop, and to my anonymous reviewers for their meticulous and helpful comments and suggestions.

Bailly JC and Morgan RC (1995) Dorothea Tanning. Bailly JC (ed.). New York: G. Braziller. Barron S (1991) Degenerate art: the fate of the avant-garde in Nazi Germany. Los Angeles County Museum of Art.

Baudrillard J and Turner C (2012) The spirit of terrorism ; and, Other essays. London: Verso.

Baur M (2005) what is distinctive about terrorism and what are the philosophical implications. In: Shanahan T (ed.) Philosophy $9 / 11$ : thinking about the war on terrorism. Illinois: Open Court, pp. 3-21.

Benjamin W (1999) Surrealism: The Last Snapshot of the European Intelligentsia. In: Walter Benjamin: Selected Writings, vol 2, 1927-1934. Cambridge, MA: Harvard University Press, pp. 201-221.

Benjamin W and Zorn H (1968) Theses on the Philosophy of History. In: Arendt H (ed.) Illuminations: Walter Benjamin. London: Pimlico: 145-155.

Breton A, trans Seaver R and Lane HR (1969) Manifestoes of surrealism. Ann Arbor: University of Michigan Press.

Bruhm S and Hurley N (2004) Curiouser : on the queerness of children. Minneapolis: University of Minnesota Press.

Bury JB (1920) The Idea of Progress: An Inquiry Into its Origin and Growth. London: MacMillan and Co.

Campos NG (2014) Children in armed conflict. Gazeta de Antropologia. UNICEF. Caws MA (1997) The surrealist look: an erotics of encounter. London : MIT Press.

Chung S and Walsh DJ (2000) Unpacking child-centredness: A history of meanings. Journal of Curriculum Studies 32(2): 215-234.

Cobb M (2005) Childlike: Queer Theory and Its Children. Criticism 47(1): 119-130.

Conley K (2013) Surrealist Ghostliness. Lincoln: University of Nebraska Press.

Coveney P (1957) Poor Monkey: The Child in Literature. London: Rockliff.

Crimmins K (2006) Expressions of terror: Rethinking Islamist terorism as communiciative praxis. In: Crimmins $\mathrm{K}$ and De Vriese $\mathrm{H}$ (eds) The reason of terror : philosophical responses to terrorism. Leuven: Peeters, pp. 209-234.

Duffy N (2017) Online Christian extremist mocks 'pro-Sodomite' Ariana Grande fans after 
Jessop, S. (2018). How modernity's futurism puts children in the front line. Childhood.

Manchester attack. Pink News, 23 May. London.

Edelman L (2004) No future : queer theory and the death drive. Durham, NC: Duke

University Press.

Forgács Éva (2014) Modernism's Lost Future. Filozofski vestnik 35(2). Akademija: 29-45.

Glăvan G (2016) Corrupt Childhood. Dorothea Tanning's Chasm: a Weekend. British and American Studies 22: 57-64.

Halperin DM (1995) Saint Foucault : towards a gay hagiography. Oxford: Oxford University Press.

Haring K and Fairey S (2010) Keith Haring journals. London: Penguin.

Herbert RL (1997) The Arrival of the Machine: Modernist Art in Europe, 1910-1925. Social Research 64(3): 1273-1305.

Hopkins D (2004) Dada and Surrealism : a very short introduction. Oxford: Oxford University Press.

Hopkins D (2014) Duchamp, Childhood, Work and Play: The Vernissage for First Papers of Surrealism, New York, 1942. Tate Papers 22.

Hopkins David (2016) Re-enchantment: surrealist discourses of childhood, hermeticism and the outmoded. In: Hopkins D (ed.) A Companion to Dada and Surrealism. Chichester: John Wiley \& Sons: 270-287.

Humphreys R (1999) Futurism. London: Tate Gallery.

James A, Jenks C and Prout A (1998) Theorizing childhood. London: Polity Press.

Jay M (1973) The dialectical imagination: a history of the Frankfurt School and the Institute of Social Research 1923-1950. Berkeley: University of California Press.

Jenks C (1996) Childhood. London: Routledge.

Jones D (2014) Dada 1916 in theory : practices of critical resistance. Liverpool: Liverpool University Press.

Kennedy D (1989) Fools, Young Children, Animism, and the Scientific World View. Philosophy Today 33(4): 374-380.

Kennedy D (2013) Epilogue : Becoming Child, Becoming Other : Childhood as Signifier. In: Muller A (ed.) Childhood in the English Renaissance, Trier, Wissenschaftlicher Verlag Trier: 145-153.

Key E (1900) The Century of the Child. New York and London: G. P. Putnam's Sons.

Key E (1914) The Younger Generation. Trans. Arthur G. Chater (ed.). New York and London: G. P. Putnam's Sons.

Löwy M and Sayre R (2001) Romanticism against the tide of modernity. Durham, NC: Duke University Press.

Mahon A (2007) Eroticism and Art. Oxford: Oxford University Press.

Marcus S (1984) Freud and the Culture of Psychoanalysis: Studies in the Transition from 
Jessop, S. (2018). How modernity's futurism puts children in the front line. Childhood.

Victorian Humanism to Modernity. Boston: Allen and Unwin.

Matthews J (2014) Media performance in the aftermath of terror: reporting templates, political ritual and the UK press coverage of the London bombings, 2005. Journalism $17(2)$.

McAra C (2011) Surrealism's Curiosity: Lewis Carroll and the Femme-Enfant. Papers of Surrealism (9).

Myers-walls JA (2008) Journal of Aggression, Maltreatment \& Trauma Children as Victims of War and Terrorism. 6771(July 2014): 37-41.

Nietzsche FW (2008) The birth of tragedy. Oxford: Oxford University Press.

O'Kane RHT (2007) Terrorism. London: Pearson Longman.

Peters O (2014) Degenerate art : the attack on modern art in Nazi Germany, 1937. London: Prestel Publishing.

Pippin RB (1999) Modernism as a Philosophical Problem: On the Dissatisfactions of European High Culture. London: Wiley.

Plotz JA (2001) Romanticism and the vocation of childhood. Basingstoke: Palgrave Macmillan.

Rainey LS, Poggi C and Wittman L (2009) Futurism : an anthology. New Haven: Yale University Press.

Rawlinson M (2017) How the British press reacted to the Manchester bombing. Guardian, 22 May. London.

Richter H (1965) Dada: Art and Anti-Art. London: Thames and Hudson.

Ridley L (2015) 7/7 Bombings: How Newspaper Front Pages Covered Britain's First Ever Suicide Attacks. Huffington Post, 7 July.

Rush C (2013) Controversial U.S. professor James Kincaid slams critics who call him an advocate for pedophilia. Toronto Star, 19 October. Toronto.

Ryan KW (2011) The new wave of childhood studies: Breaking the grip of bio-social dualism? Childhood 19(4): 439-452.

Spender S (1963) The Struggle of the Modern. London: Hamish Hamilton.

Stavrinaki M (2016) Dada Presentism: An Essay on Art and History. Stanford: Stanford University Press.

Stockton KB (2009) The queer child, or growing sideways in the twentieth century. Durham, NC: Duke University Press.

Strom K (2002) Making History: Surrealism and the Invention of a Political Culture. Lanham, Md.: University Press of America.

Tanning D (1990) Statement (1989). In: Caws MA, Kuenzli R, and Raaberg G (eds.) Surrealism and Women. Cambridge, MA: MIT Press: 228. 
Jessop, S. (2018). How modernity's futurism puts children in the front line. Childhood.

The United Nations (1989) Convention on the Rights of the Child (UNCRC).

Tuman JS (2010) Communicating terror : the rhetorical dimensions of terrorism. London: Sage.

Waldberg P (1965) Surrealism. London: Thames and Hudson. 